\title{
実大震動台実験に基づく戸建免震住宅の免震層変形抑制に関する研究 A STUDY ON RESTRAINING DEFORMATION OF THE SEISMIC-ISOLATED LAYER OF HOUSES BASED ON SHAKING TABLE TESTS OF A FULL-SCALE HOUSE
}

高橋 武宏*, 天埜貴仁**, 福和伸夫***

Takehiro TAKAHASHI, Takahito AMANO and Nobuo FUKUWA

\begin{abstract}
It is necessary to prepare to strong ground motion beyond our previous assumptions, for instance like a Huge Nankai quake. But with current seismic-isolated house technology, we believe that the deformation of the seismic-isolated layer becomes so big that it exceeds the capacity of the equipment, causing extensive damage to the houses. Therefore, the authors developed devices that restrain deformation of the seismic-isolated layer, and measured the equipment efficiency and vibration properties by shaking table tests of a full-scale house. As a result, by installing the newly-developed oil damper, the building itself did not have substantial damage even with the restrained seismic-isolated layer deformation, and we could prevent overturning of the furniture in the house.
\end{abstract}

Keywords : Seismic-isolated house, Restraining deformation of the seismic-isolated layer, Shaking table tests of a full-scale house 戸建免震住宅，免震層変形抑制，実大震動台実験

\section{1. はじめに}

2011 年東北地方太平洋沖地震 (以後、3.11) では長周期長時間地震 動による高層建物の共振問題が露呈したが 1)、免震建物は建物とし ての機能を損なうような被害は見られず、全般的には良い免震効果 を発揮したとされた ${ }^{2)}$ 。しかし、個々に見ると宮城県内で免震層変 形が $40 \mathrm{~cm}$ を超えたもの、震源から離れた東京都や神奈川県で免震層 変形が大きいものがあった ${ }^{2,3)}$ 。また極く少数ではあるが、戸建免 震住宅においても宮城県と神奈川県の一部の地域で地震時設計限界 変形 $30 \mathrm{~cm} \sim 33 \mathrm{~cm}$ に達し、風ストッパー装置が作動する状況が局所的 に見られた ${ }^{4)}$

免震建物は設計時の想定を超える強い地震動、若しくは想定と異 なる周期特性の地震動を受けて、免震層変形が免震層クリアランス に達した場合、応答加速度の低減効果を瞬時に失う可能性がある。 免震層の衝突速度によって、ストッパー装置や擁壁への軽微な接触 から深刻な衝突まで様々な状況が考えられる。また擁壁の剛性によ っては上部構造に与える衝撃力が非免震建物の地震力を凌駕するこ とも十分に考えられ 5)、咒長性に欠ける一面を持っている。

3. 11 によってマグニチュード (Mw) 9 クラスの巨大地震発生が現実 のものとなり、来る南海トラフ巨大地震の想定地震規模が見直され た ${ }^{6)}$ 。震源が陸域に達するため、首都圈をはじめ東海、近畿、四国、 九州など広範囲で強い摇れを受け、トラフ沿いの付加体の存在によ って長周期成分を遠くまで伝達すると言われている。断層破壊の連 動の仕方によっては摇れの継続時間が 3.11 に対して数倍長くなる
可能性もあると指摘されており7)、これらは全て免震層変形を増大 させる要因となる。

このような背景の下、近年では実大免震建物を擁壁へ衝突させて 限界状態を把握する害験的研究 ${ }^{8,9}$ ) 、免震層変形を抑制して衝突 を回避するための付加減衰装置 (以後、変形抑制装置) の研究開発が 進められている例隹は 10,11)。これら多くの変形抑制装置に共通してい るのは、通常の設計時に想定する地震動に対しては設置しない状態 と遜色ない程度に応答加速度を低減し、それを上回る地震動に対し ては応答加速度の増大を覚悟して免震層変形を目標值内に抑制する という設計思想である。しかし、通常の設計レベルを上回る地震動 強さの設定、免震層の変形抑制時に許容寸る応答加速度など、具体 的なクライテリアについては社会的に十分に合意されていない。

本研究は周期 2 秒から 3 秒程度の戸建免震住宅を対象とし、過去 に日本国内で観測され免震層変形が極めて大きくなる実地震動に対 して上部構造の応答加速度を建物内部の家具類を転倒させないレ心゙ ルに保ちながら、免震層変形を現実的な大きさに抑える変形抑制装 置の開発を目的とする。そこで、実大震動台実験に基づく実証的な 見地から変形抑制装置の性能及び上部構造の振動性状を検証する。

\section{2. 戸建免震住宅の実情}

\section{1 累積建築棟数と建築地分布}

本論文では 1 社の住宅メーカーが 1999 年以降に供給を始めた木造 軸組構法による戸建免震住宅 (以後、免震住宅)を研究対象とする。
* 名古屋大学減災連携研究センター 研究員 ·工修

** 名古屋大学大学院環境学研究科 博士課程前期

*** 名古屋大学減災連携研究センター センター長・教授・工博
Researcher, Disaster Mitigation Research Center, Nagoya University, M. Eng. Graduate Student, Graduate School of Environmental Studies, Nagoya University

Prof., Disaster Mitigation Research Center, Nagoya University, Dr. Eng. 
図 1 内の折れ線グラフに示寸通り、年間 400 棟のほぼ一定のペー スで建築しており、2011 年 3 月末での累積建築棟数は約 4000 棟 ${ }^{12)}$ にのぼる。静岡県及び愛知県で全体の半数以上を占めており、次に 神奈川県、東京都などが多い。東海地震や関東地震の再来が懸念さ れる地域で普及率が高い傾向が見られる。

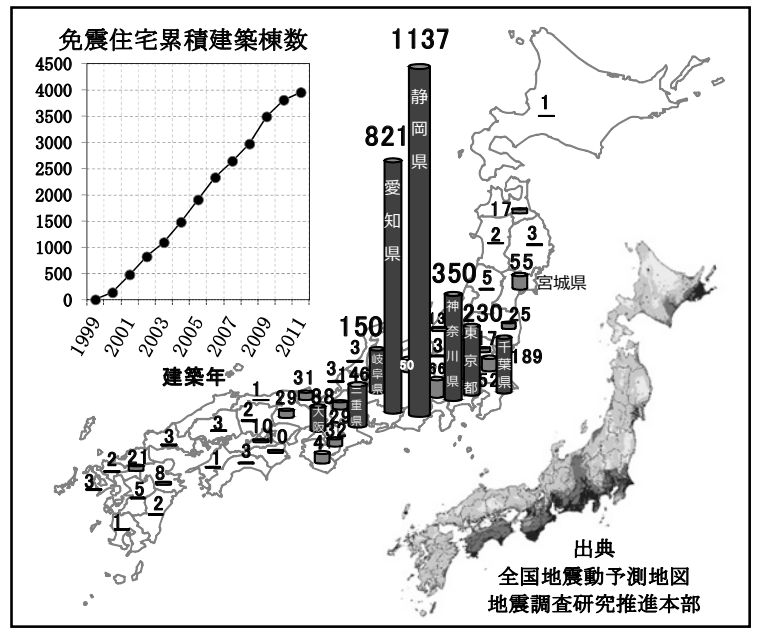

図 1 免震住宅の累積建築棟数と建築地分布

\section{2 免震システム}

研究対象とした免震住宅はすべり支承と積層ゴムで構成される (図 2)。す心゙り支承は低摩擦 $(\mu=4.5 / 100)$ と高摩擦 $(\mu=6.5 / 100)$ の 2 種類があり、鉛直支持機能と減衰機能を担う。積層ゴムは天然 ゴム系（弾性剛性 $k_{r}=0.385 \mathrm{kN} / \mathrm{cm} ）$ と高減衰ゴム系 $\left(k_{r}=0.245 \mathrm{kN} / \mathrm{cm}\right)$ の 2 種類があり、弾性復元機能と減衰機能の一部を担う。これらの 組み合わせで 4 種類の免震システムが存在し、建築地の地盤振動特 性によって建物毎に最適な免震システムが選択される。また、極く 稀な暴風時の免震層過大変形防止のため、風ストッパー装置(作動開 始変形は $30 \mathrm{~cm} \sim 33 \mathrm{~cm}$ 、以後、ストッパー)を併設している ${ }^{4)}$ 。

\subsection{11における免震層変形抑制と被災状況}

3.11 では広範囲で強い摇れとなり、住宅メーカーが実施した震災 後の調査では 400 棟に近い免震住宅において免震層が滑動した跡が 見られた。これらの多くは免震効果を発揮していたが ${ }^{13)}$ 、宮城県大 崎平野の 1 棟は液状化に伴う地盤被害の直接的影響を受けていた。 また宮城県仙台平野の 2 棟 ${ }^{14)}$ では比較的軟弱と推察される表層部の 影響によって、さらに神奈川県足柄平野の 3 棟 ${ }^{4)}$ では複雑な地形に おける深部地盤震動特性による共振によって設計限界変形を超える 免震層変形が生じ、ストッパーによって過大な変形が抑制された。

仙台平野の 2 棟ではストッパーの基礎側固定金具の一部浮き上り や、鉄骨土台梁への固定ボルトの一部損傷が見られた。しかし、建 物内部は食器棚の座りの悪いものが転倒した程度で、施主へのヒア リングでは隣家の状況と比較すると極々軽微な被害だと判断されて いた。一方、足柄平野の 3 棟では固定ボルトの多くが破断しており、 ストッパーに大きな荷重が作用したことが推察された。上部構造の 著しい損傷は見られなかったが、建物内部では家具転倒、什器飛散、 食器類の落下によるガラス散乱、壁紙の一部に亀裂などが見られた。 施主へのヒアリングでは大きな衝撃が数回生じたようで、適切な免 震性能を確保できなかったことが明らかになった。

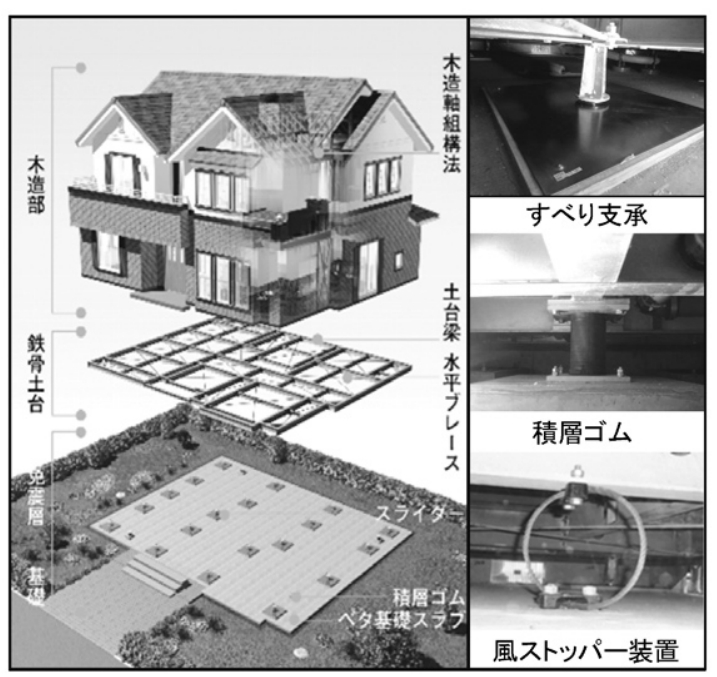

図 2 免震システム

\section{4 施主の安全と心情を考慮した変形抑制装置の必要性}

図 3 に免震住宅を建築した 施主の職業を示す。公務員が 約 2 割を占める(円グラフ突 出部）。総務省の統計 ${ }^{15)}$ によ る我が国の総労働人口 6300 万人に対する公務員の割合が 大凡 $5 \%$ であることを考える と、高い割合である。公務員 の内訳では教職員が最も多く、

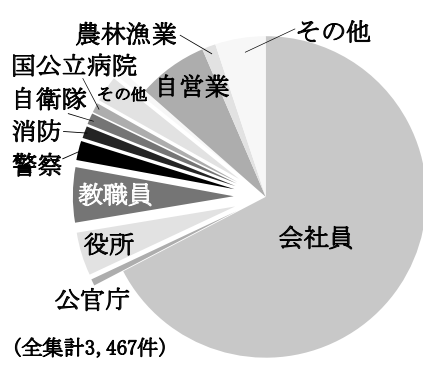

図 3 施主の職業 警察、消防、自衛隊関係者、 役所(都道府県、市区町村)など、防災関係従事者も多い。

一方、施主の中には本音では地震を待ち望む人もいるようだ。免 震システムに投資した効果は地震時にしか分からないのと、大規模 地震ほど非免震住宅との差別化が明確になるので、不謹慎ではある が、施主の心理はある意味理解できる。これとは逆に、過去の被災 経験によるトラウマから二度と摇れの恐怖を思い出したくないと いう理由で免震住宅を選択したケースも稀にある。このように免震 住宅には施主の大きな期待と様々な心情が詰まっている。

また、2004 年新潟県中越地震で亡くなった 51 名の内、実に半数 近くが地震の摇れが引き起こすショックやその後のストレスに影響 されたものという報告 ${ }^{16)}$ もある。以上を考慮すると、たとえ想定 外の地震動であっても免震住宅に大きな衝撃力を与えるような変形 抑制装置の採用は適切ではないと思われる。

\section{5 免震層変形抑制の検証が必要な地震動}

免震建物は 1995 年阪神淡路大震災を契機に急増した ${ }^{17)}$ 。神戸海 洋気象台で観測された強震動 (以後、神戸波) は公的機関のデータで 公表も早く、震災の帯 ${ }^{18)}$ からは外れた地点での観測地震動だが、兵 庫県南部地震を代表する地震動として数多くの解析と震動台実験に 用いられてきた ${ }^{19)}$ 。周期 1 秒程度のパルス波を含み、3 章に詳細を 示寸が、対象免震住宅の場合は応答加速度の低減率が高く、免震層 変形が免震装置の可動範囲内に納まるという特徵がある。このため、 免震性能のアピールにはある意味最適な地震動であった。一方で震 災の帯内の JR 鷹取波( 以後、鷹取波)、大阪ガス莫合波 (以後、莫合 
波)については、民間データという事情や原波が震動台で再現できな い大きな地動変位であるという理由もあり、対象免震住宅も含めて、 免震建物の応答検証や設計に用いられることは稀であった。

3.11 以降、長周期地震動による共振問題に焦点が当てられる風潮 があるが、断層近傍の指向性パルス波に対しては地動変位がそのま ま免震層の最大変形となり、共振しなくても瞬間的に大きく変形す る可能性がある ${ }^{20)}$ 。このため、2004 年中越地震における JMA 川口波 (以後、川口波)、2007 年新潟県中越沖地震における K-NET 柏崎波 (以 後、柏崎波)など、断層近傍の地震動でかつ免震周期周辺で告示の地 震動強さを上回るものについても積極的に設計に考慮するべきと考 える。筆者らは将来発生が懸念される巨大地震動による安全性検証 を最終的な目標と考えているが、模擬地震動には様々なパラメータ、 仮定、計算方法により大きな幅が付きまとう。そこで将来の巨大地 震動に備えるための必要条件として、本研究では過去日本国内で実 際に観測された最大級の地震動の中で免震住宅にとって厳しい応答 となる地震動に対し、免震層変形を現実的な大きさに抑制する方策 について検討することが先決であると考えた。

\section{3. 実大震動台実験概要}

免震住宅用の変形抑制装置の開発と性能検証のため、兵庫県三木

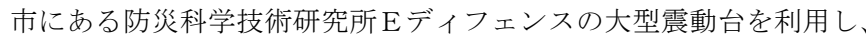
2011 年 7 月から 2012 年 7 月の 1 年間に合計 4 期に及ぶ実大震動台 実験を実施した。本研究では表 1 に示寸 1 期及び 4 期で実施した変 形抑制装置の主要な加振結果について詳細に検討する。

\section{1 実験対象住宅の構成}

図 4 に実験対象住宅の構成を示す。上部構造は間口 $10.01 \mathrm{~m}$ 奥行き 8. $19 \mathrm{~m}$ 、延床面積 $148.1 \mathrm{~m}^{2}$ の 2 階建て木造軸組構法で、 1 期と 4 期、 共に同一間取りである。1 期ではたすき掛けまたは片筋かいによる
表 1 実大震動台実験の概要

\begin{tabular}{|c|c|c|}
\hline 期 & 実験期間 & 変形抑制装置の形式と名称 \\
\hline 1 & $\begin{array}{l}2011 \text { 年 } 7 \text { 月 } \\
25 \text { 日 } 28 \text { 日 (4日間) }\end{array}$ & 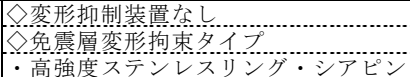 \\
\hline & 2012年7月 & $\triangleright$ 兔震層忘答速度感応タイプ \\
\hline & 5,6 日、17〜20日（6日間） & ・特殊オイルダンパ \\
\hline
\end{tabular}

表 2 上部構造の耐震性能

\begin{tabular}{|c|c|c|c|c|c|c|}
\hline 期 & 階 & 方向 & 存在壁量 (m) & 必要壁量 (m) & 壁量余裕度 & 偏心率 \\
\hline \multirow{4}{*}{1} & \multirow{2}{*}{2} & $X$ & 21.84 & 15.01 & 1.46 & 0.03 \\
\hline & & Y & 20.02 & 15.01 & 1.33 & 0.07 \\
\hline & \multirow{2}{*}{1} & $X$ & 41.86 & 25.27 & 1.66 & 0.07 \\
\hline & & Y & 43.68 & 25.27 & 1.73 & 0.21 \\
\hline \multirow{4}{*}{4} & \multirow{2}{*}{2} & $X$ & 39.13 & 15.01 & 2.61 & 0.04 \\
\hline & & $\mathrm{Y}$ & 36.86 & 15.01 & 2.46 & 0.07 \\
\hline & \multirow{2}{*}{1} & $X$ & 62.11 & 25.27 & 2.46 & 0.06 \\
\hline & & Y & 50.05 & 25.27 & 1.98 & 0.17 \\
\hline
\end{tabular}

耐力壁とし、4 期ではこれに加え厚さ $9 \mathrm{~mm} の$ 構造用合板を釷留めし ている。内壁は厚さ $12.5 \mathrm{~mm}$ の石膏ボード貼り、壁紙クロス仕上げで ある。外壁は厚さ $12 \mathrm{~mm}$ のセメント系サイディングで、一部タイル張 りとしている。また、建物内部の生活環境の安全性を確認するため、 室内に様々な家具や日用品、照明器具を設えている。

表 2 に建築基準法施行令第 46 条に基づいて算定した、実験対象住 宅の存在壁量と地震力 (重い屋根) に対する必要壁量を示す。対象免 震住宅としては標準的な耐震性能で、壁量余裕度から 1 期では住宅 品質確保促進法における耐震等級 $2 、 4$ 期では耐震等級 3 に相当する。 また、加振前に住宅全体を大型ロードセルに載せて計測し、免震層 及び積載荷重を含めた総重量を 1 期と 4 期、共に $490 \mathrm{kN}$ に調整した。

免震システムは、 1 期では低摩擦すべり支承 $(\mu=4.5 / 100) 17$ 基と 天然ゴム系積層ゴム $\left(k_{r}=0.385 \mathrm{kN} / \mathrm{cm}\right) 4$ 基を基本構成とした。変形抑 制装置がない状態での免震層の最大変形を検証するため、Y 方向の み、すべり支承の可動部を片振幅 $1 \mathrm{~m}$ まで拡幅している。鉄骨土台梁

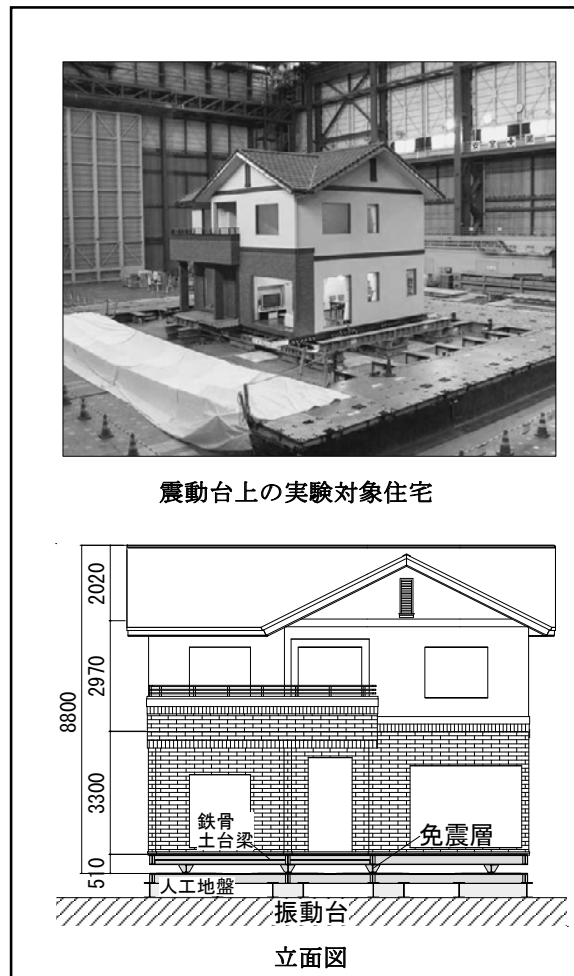

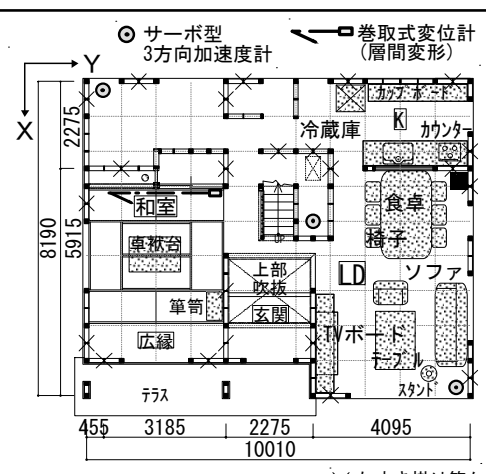

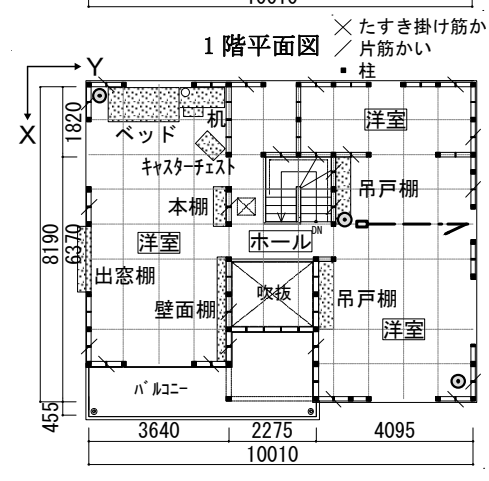

2 階平面図

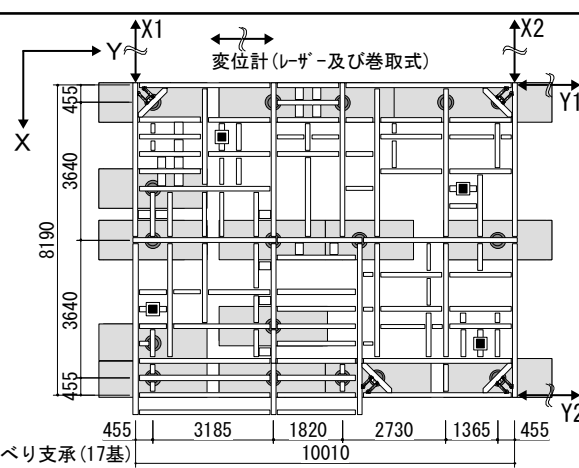

○すべり支承(17基)

口 積層ゴム(4基) $Y \quad 1$ 期 免震層装置配置図

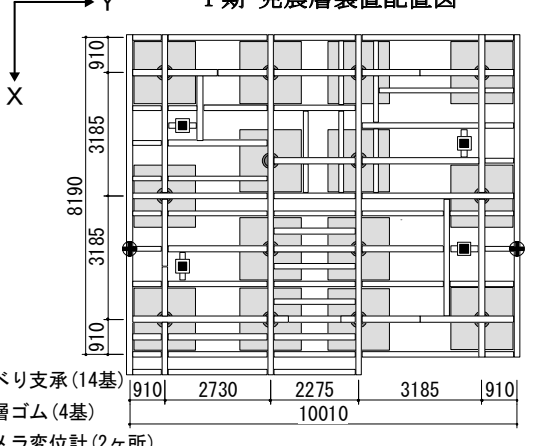

4 期 免震層装置配置図

図 4 実験対象住宅の構成 
は H-250*125 で、すべり支承からの外周部跳ね出し長さを $455 \mathrm{~mm}$ と した。一方、 4 期では摩擦係数を 0.03 程度に下げた低摩擦すべり支 承 14 基と高減衰積層ゴム $\left(k_{r}=0.245 \mathrm{kN} / \mathrm{cm}\right) 4$ 基を基本構成とした。 鉄骨土台梁は H-300*150 で、跳ね出し長さを $910 \mathrm{~mm}$ とした。

建物総重量と積層ゴム 4 基の $k_{r}$ から決まる免震層の接線周期 $T_{t}$

は 1 期約 3.6 秒、 4 期約 4.5 秒で、すべり支承の摩擦力を含めた免 震層 $20 \mathrm{~cm}$ 変形時の復元力特性から算出した等価周期 $T_{e}$ はそれぞれ 2.7 秒 $(0.37 \mathrm{~Hz}) 、 3.2$ 秒 $(0.31 \mathrm{~Hz})$ 、等価減衰定数 $h_{e q}$ は共に約 $25 \%$ で ある。

図 5 に各期加振初日の最初に 実施したホワイトノイズ加振 $\left(50 \mathrm{~cm} / \mathrm{s}^{2}\right)$ による、1 階床中央に 対する軒中央の伝達関数を示す。 伝達関数のピークから、上部構 造の一次固有振動数は 1 期では $\mathrm{X}$ 方向 $5.2 \mathrm{~Hz} 、 \mathrm{Y}$ 方向 $3.3 \mathrm{~Hz} 、 4$ 期では外壁の構造用合板により 剛性が上がり、X 方向 $5.6 \mathrm{~Hz} 、 \mathrm{Y}$ 方向 $4.5 \mathrm{~Hz}$ と推定される。

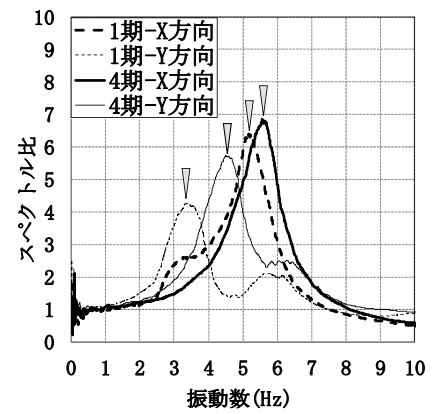

図 5 伝達関数
$\mathrm{Y}$ 方向は開口部が多く、特に 1 期では一次固有振動数が小さいが、 免震層の振動数 $\left(1 / T_{e}\right)$ に対しては約 10 倍大きいことから、免震層に 対する上部構造微小変形時の水平剛性は大凡 100 倍と推測される。

変形抑制装置に関しては表 1 に示寸通り、1 期と 4 期とで異なる 形式の方法を考えた。1 期では免震層変形が大凡 $30 \mathrm{~cm}$ に達するまで は作動せず、これを超えると急激に剛性が上がる免震層変形拘束夕 イプで、減衰を殆ど伴わない。大規模免震建物における擁壁の役割 を想定している。

4 期では免震層の応答速度に応じて減衰力が変化する特殊オイル ダンパを採用した。一般的なオイルダンパと比較して、応答速度と 減衰力の関係に特徵がある。各装置の詳細については 4 章及び 5 章 で説明する。また、 1 期では変形抑制装置の性能確認に先立ち、装 置を設置しない状況下での免震層の最大変形及び応答速度の確認も 行う。

\section{2 入力波}

1 期では、足柄平野で共振が生じた免震住宅の近くに位置する東 京大学地震研究所の強震観測網 SK-net で観測された長周期地震動 を 3 方向一律 $150 \%$ に拡幅したもの (以後、足柄波) と ${ }^{4)}$ 、断層近傍の 巨大地震動である川口波及び柏崎波を主な入力波とする。

4 期ではこれらに加え、鷹取波、莫合波、神戸波、3.11 における $\mathrm{K}-\mathrm{NET}$ 古川波 (以後、古川波) 、模擬波として上町断層 (A3 ゾーン、レ ベル $3 \mathrm{C}$ パルス型、以後、上町断層波) と、告示 2 種地盤八戸位相波 (以 後、告示波) を選定し、多種多様な地震波に対する応答を検証する。

図 6 に入力波及び告示波 2 種地盤簡略法による疑似速度応答スペ クトル $S_{v}$ (減衰 $5 \%$ 、水平 2 方向の相乗平均) を重悋て示す。

\section{3 変形抑制装置を設置しない状態の振動特性}

変形抑制装置を設置しない状況における免震層の最大変形及び応 答速度を把握するため、実験対象住宅に足柄波、川口波、柏崎波を 用いて 3 軸加振を行う。免震層の最大変形が生じる速度主軸成分を 震動台の Y 方向に、その直交方向成分を X 方向に入力するように加 速度データを座標変換 (以後、Y 主軸加振) している ${ }^{21)}$ 。
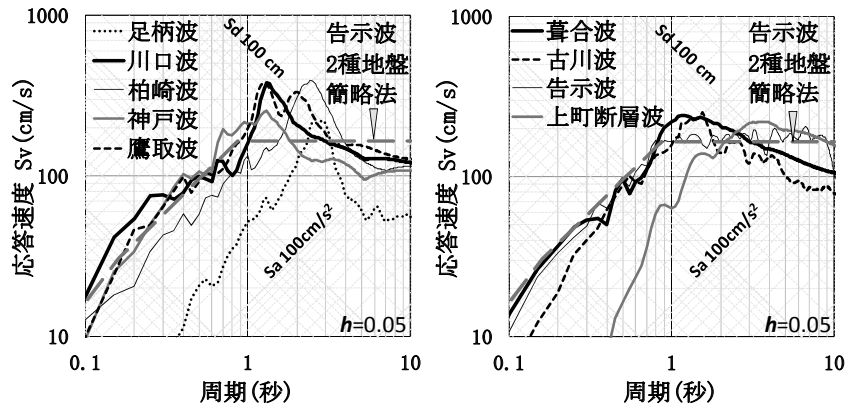

図 6 入力波の疑似速度応答スペクトル

事前の解析において免震層の最大変形が天然ゴム系積層ゴムの破 断変形 $(50 \mathrm{~cm}$ 程度) を上回ると推測されたので、本実験では免震シス テムを高摩擦すべり支承と高減衰積層ゴムの組み合わせとした。尚、 高減衰積層ゴムの破断変形は $75 \mathrm{~cm}$ 程度である。

また、参考のために 2006 年に実施された「大都市大震災軽減化特 別プロジェクト」(以後、大大特)における木造免震住宅の想定外入 力実験 ${ }^{22)}$ の一部で、変形抑制装置がされていない状況の神戸波及び 鷹取波加振の実験結果を示す。この時の実験対象住宅の上部構造、 免震システム (すべり支承及び積層ゴム) は本実験と同様である。

図 7〜10 に $\mathrm{Y}$ 主軸加振した震動台 $\mathrm{Y}$ 方向における免震層復元力特 性を示す。足柄波では $30 \mathrm{~cm}$ 程度、川口波、柏崎波では $70 \mathrm{~cm}$ を超え る極めて大きな免震層変形となっている。参考データの神戸波では $15 \mathrm{~cm}$ 程度、鷹取波では $60 \mathrm{~cm}$ に達する。同じ兵庫県南部地震でも免 震層変形に著しい差が生じることが分かる。

免震層変形が $50 \mathrm{~cm}$ 付近から積層ゴムのハードニングが見られる が、最大変形時の免震層せん断力係数は 0.3 程度である。免震住宅 のクリアランスが $1 \mathrm{~m}$ 程度確保できれば免震性能として問題はない が、大きなクリアランスは敷地の有効利用を妨げ、現実的ではない。

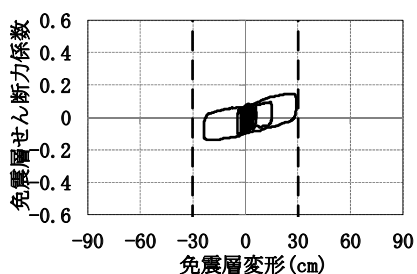

図 7 足柄波

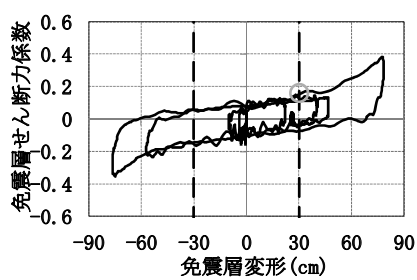

図 9 柏崎波

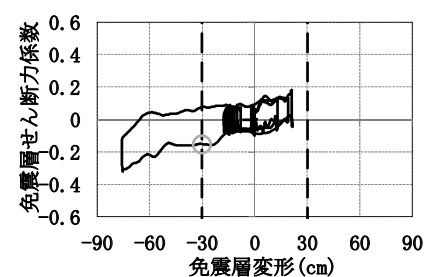

図 8 川口波

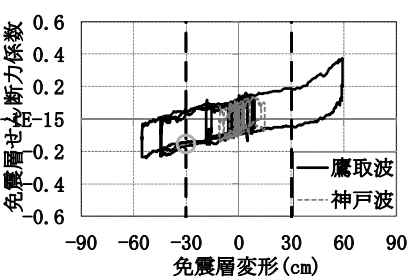

図 10 神戸波及び鷹取波 (参考)
図 11〜14 に免震層変形と応答速度の関係を示す。足柄波や神戸波 では $100 \mathrm{~cm} / \mathrm{s}$ 以下の応答速度だが、川口波、柏崎波、鷹取波では最 大応答速度が $200 \mathrm{~cm} / \mathrm{s}$ に達している。免震システムが低摩擦すべり 支承と天然ゴム系積層ゴムの組合せの場合には、免震層変形や応答 速度は更に大きくなると推測できる。 


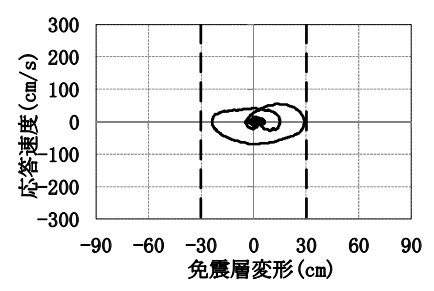

図 11 足柄波

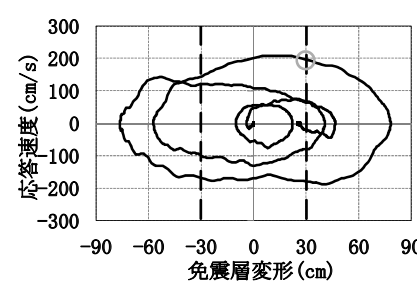

図 13 柏崎波

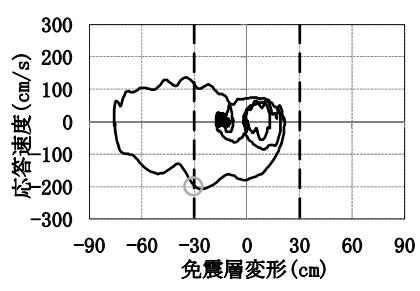

図 12 川口波

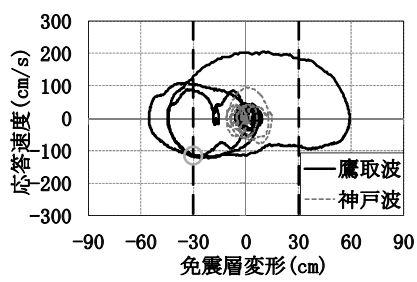

図 14 神戸波及び鷹取波 (参考)
このような地震動に対しては適切に変形抑制しなければ、ストッ パーの破断、すべり支承設置架台からの脱落とそれに伴う上部構造 への大きな衝撃、更には積層ゴムの破断による隣家への越境など、 甚大な被害となることが容易に推測できる。

対象免震住宅や転がり系支承を有寸る免震住宅全般において、免 震装置の可動範囲は $30 \mathrm{~cm}$ 前後であることから、目安としてグラフ中 に免震層変形が $30 \mathrm{~cm}$ の地点を太点線で、また応答が最初に $30 \mathrm{~cm}$ に 到達する地点を丸印で示す。川口波では瞬間的に $70 \mathrm{~cm}$ 変形し、その 変形過程の $30 \mathrm{~cm}$ 地点では応答速度が $200 \mathrm{~cm} / \mathrm{s}$ に達している。柏崎波 では初回 $30 \mathrm{~cm}$ 変形時の応答速度は $70 \mathrm{~cm} / \mathrm{s}$ 程度であるが、その後繰 り返し変形しながら速度を増して $200 \mathrm{~cm} / \mathrm{s}$ を超える応答となる。鷹 取波についても同様の傾向が見られ、変形抑制時の速度変化に伴う 大加速度の発生が憅念される。

\section{4. 実大震動台実験第 1 期 : 免震層変形拘束タイプ}

通常、免震住宅はピット型の免震層を有しておらず、擁壁に衝突 させることはできない。そこで、擁壁に代わる高い剛性と強度で過 大な変形を拘束する 2 種類の変形抑制装置を考える。本章では既存 免震住宅の最大可動範囲 $35 \mathrm{~cm} \sim 40 \mathrm{~cm}$ 程度を念頭に置き、3 章で示す 地震動に対して免震層の最大変形を抑制することを前提にする。尚、 免震システムはシステム中で最も減衰が少ない低摩擦すべり支承と 天然ゴム系積層ゴムの組み合わせとし、変形抑制装置の作動変形を $30 \mathrm{~cm}$ 程度に設定する。

\section{1 高強度ステンレスリング}

免震システムに付随するリング状の風ストッパー装置を高強度化 して、地震動に対する変形抑制装置とする。風ストッパー装置は大 大特にて強度不足であったため、リングの断面積を約 2 倍に増し、 固定ボルトをM16 高力ボルト (F10T) に変更して強度を高めている。

図 15 に作動模式図を示す。作動変形まではリングの緩みによって 機能しないが、それを超えると引張力が生じる。作動時に若干の衝 撃緩衝を期待して、震動台実験時には取り付け部に厚さ $10 \mathrm{~mm}$ のス レンブタジエンゴム板 4 枚を挿入しているが、ステンレスリング自 体にエネルギ吸収能力は無い23)。

図 16 に上下固定金具を含めた (ゴム板は含まない)、静的せん断実 験の結果を示す。固定金具は球状黒鉛鋳鉄 FCD 450-10を用い、上側
は鉄骨下フランジに M16 高力ボルト 2 本、下側は厚さ $16 \mathrm{~mm}$ の鉄板に M16 高力ボルト 2 本で固定した後、鉄板を基礎スラブに見立てた RC 部材に $M 12 \mathrm{~mm}$ 、深さ $100 \mathrm{~mm}$ の打ち込みアンカー6 本で固定している。

免震層変形 $30 \mathrm{~cm}$ 付近からリングが潰れはじめ、急激に強い引張力 が作用する。1 基あたりの破断荷重は $160 \mathrm{kN}$ 、破断時の水平変形は $35 \mathrm{~cm}$ である。破断直前までほぼ弾性的な挙動を示し、実験結果から 読み取った剛性は $K_{s}=39 \mathrm{kN} / \mathrm{cm}$ である。実験対象住宅では本装置を鉄 骨土台梁に 8 基設置する(図 17)。合計耐力は $1280 \mathrm{kN}$ で、鉄骨土台 梁の回転変形の影響を除いた場合は、建物総重量 $490 \mathrm{kN}$ に対してべ ースシア係数 2.6 相当の免震層せん断力に耐え得る。

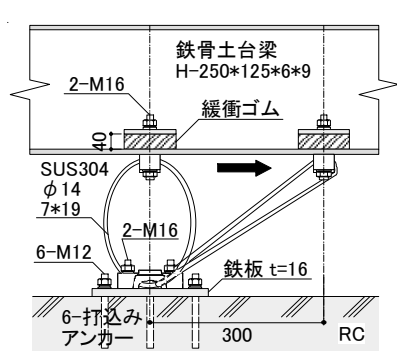

図 15 作動模式図

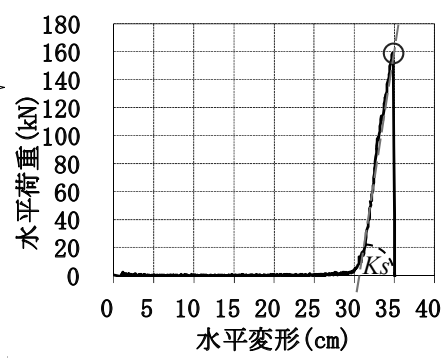

図 16 静的せん断試験結果

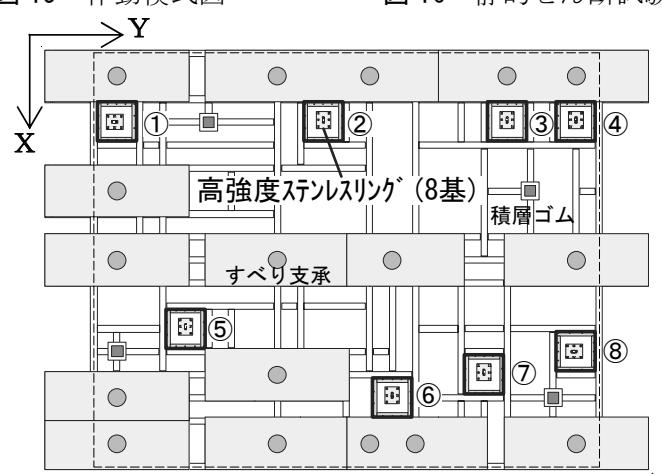

図 17 高強度ステンレスリングの配置図

\section{2 シアピン}

図 18 に作動模式図を示す。免震層変形が $30 \mathrm{~cm}$ を超えると、直径 $55 \mathrm{~mm}$ の鋼棒 (SS400) が可動部外周に設置した溝に落ち込むことでシ アピンとなり免震住宅を物理的に拘束する。その後は地震が終わる まで免震層変形の拘束状態が保たれる。溝は円周状に掘られており、 拘束時は溝に沿って多少変形できるが上部構造は非免震住宅に近い 状態となる。鋼棒は図 19 に示すシアピン受け治具に装填され、シア ピン受け治具は鉄骨土台梁下フランジに M16 高力ボルト 8 本で固定 する。シアピン作動時の鉄骨土台梁の回転変形を抑えるために、取 付けは梁の交差部に限定し、実験対象住宅では 4 配置する(図 20)。

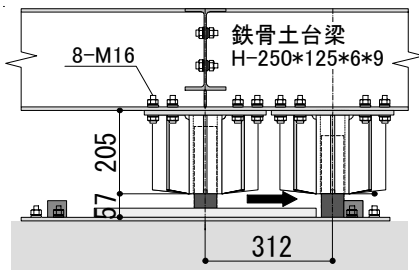

図 18 作動模式図

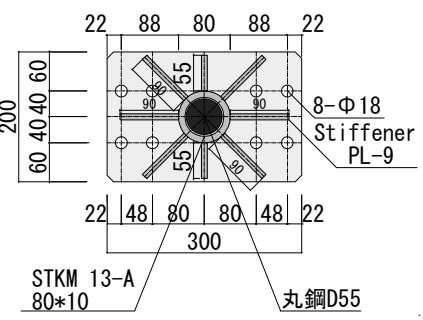

図 19 シアピン受け冶具詳細図 
鋼棒 1 本あたりの降伏せん断強度は、鋼棒の降伏せん断応力度 ${ }_{4} f_{s}=259 \mathrm{~N} / \mathrm{mm}^{2}$ に鋼棒の断面積を乗じ $600 \mathrm{kN}$ となる。合計耐力は $2400 \mathrm{kN}$ で、シアピン受け治具を剛と考え、鉄骨土台梁の回転変形の影響を 除いた場合、ベースシア係数 4.9 相当の免震層せん断力に耐え得る。

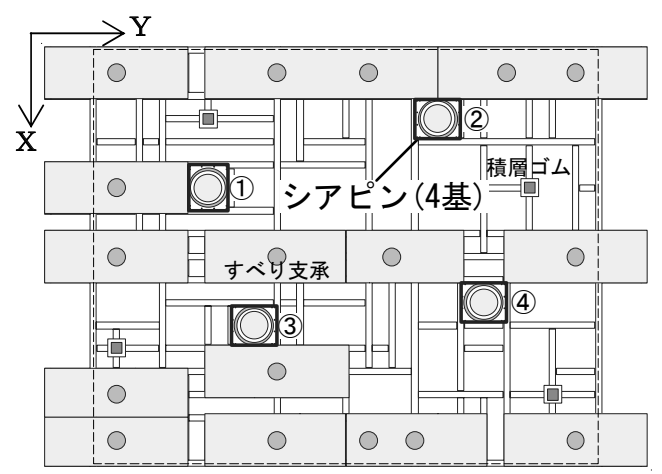

図 20 シアピン配置図

\section{3 実験結果}

図 21, 22 に足柄波 $\mathrm{Y}$ 主軸加振時の震動台 $\mathrm{Y}$ 方向における免震層変 形と免震層せん断力係数の関係を示寸。免震層変形は図 4 に示した 免震層装置配置図 (1 期) の変位計 Y1 と Y2 の平均值である。

高強度ステンレスリングでは緩やかに 3 回作動して、免震層の最 大変形を $32 \mathrm{~cm}$ 程度に抑制した。2 回目の衝突で免震層の最大せん断 力係数は 0.5 を超え、 1 階床で瞬間的に最大 $1000 \mathrm{~cm} / \mathrm{s}^{2}$ 程度の応答加 速度が生じたが、家具類の転倒は見られなかった。変形抑制後は通 常の免震性能に戻った。

シアピンでは軽い衝撃音と共に 4 基が同時に作動した。免震層変 形が拘束された時の免震層の最大せん断力係数は 0.4 程度で、高強 度ステンレスリングと同様、 1 階床で瞬間的に最大 $1000 \mathrm{~cm} / \mathrm{s}^{2}$ 程度の

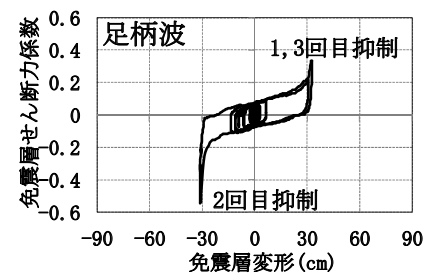

図 21 高強度ステンレスリング

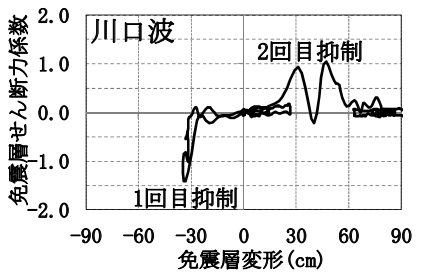

図 23 高強度ステンレスリング

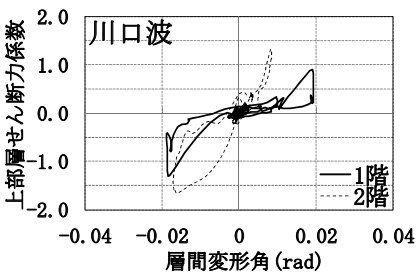

図 25 高強度ステンレスリング

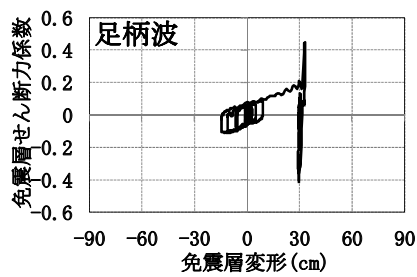

図 22 シアピン

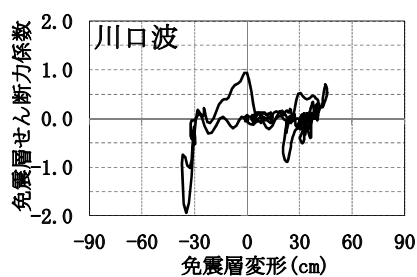

図 24 シアピン

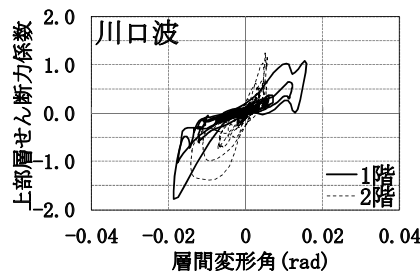

図 26 シアピン
応答加速度が生じた。変形拘束後は非免震に近い状態となったが後 続波の加速度が小さく、加振中に家具類の転倒は見られなかった。

図 23, 24 に川口波 $\mathrm{Y}$ 主軸加振時の震動台 $\mathrm{Y}$ 方向における免震層変 形と免震層せん断力係数の関係を、図 25,26 に上部構造 $\mathrm{Y}$ 方向 (中通 り)の層間変形角と層せん断力係数の関係を示す。

高強度ステンレスリングでは 1 回目の作動に対しては免震層変形 を $35 \mathrm{~cm}$ 内に抑制した。しかし、強い反動によって 2 回目の衝突が生 じ、8 基全てが破断した後に積層ゴム 4 基全てが破断し、最大変形 は $90 \mathrm{~cm}$ を超えて免震層変形を抑制することができなかった(図 27 写真 A, B, C, D)。1 階床で最大約 $3700 \mathrm{~cm} / \mathrm{s}^{2}$ の応答加速度が生じ、建 物内部のほぼ全ての家具類が転倒飛散した(図 27 写真 E, F)。

シアピンでは大きな衝撃音と共に免震層変形が一度拘束されたが、 反動と強い上下動によって 2 基のピンが溝から飛び出し、180 度反 対方向へ変形して再度拘束された (図 27 写真 $\mathrm{G}, \mathrm{H}$ )。免震層の最大せ ん断力係数は瞬間的に 2.0 に達し、衝撃によってシアピン及び鉄骨 固定部が大きく塑性変形した。また、免震層が捻じれるような挙動 が見られ、最大変形は $40 \mathrm{~cm}$ を超えた。1 階床では最大約 $4700 \mathrm{~cm} / \mathrm{s}^{2}$ の非常に大きな応答加速度が生じてほぼ全ての大型家具類が転倒飛 散し、大型冷蔵庫が踊るように前方に大きく移動するなど、建物内 部は危険な状態になることが明らかになった(図 27 写真 I, J, K, L)。

上部構造に関して、高強度ステンレスリング及びシアピン共に、 川口波加振では最大層せん断力係数は 1.0 を上回る結果となった。 倒壊には至らなかったが、 1 階の最大層間変形角は大凡 $1 / 50$ に達し、 内壁の壁紙クロスや石亳ボードに多くの亀裂や損傷が生じた。

家具類の転倒防止には壁面固定などの対策が非常に有効であるが 住宅内の実生活において転倒防止器具類の徹底は容易でなく、十分

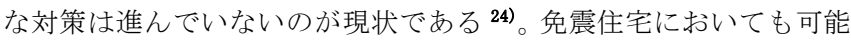
な限り家具類の固定を促すことが必要と思われるが、衝撃力をより 低減する変形抑制装置の開発が何よりも重要であると考える。
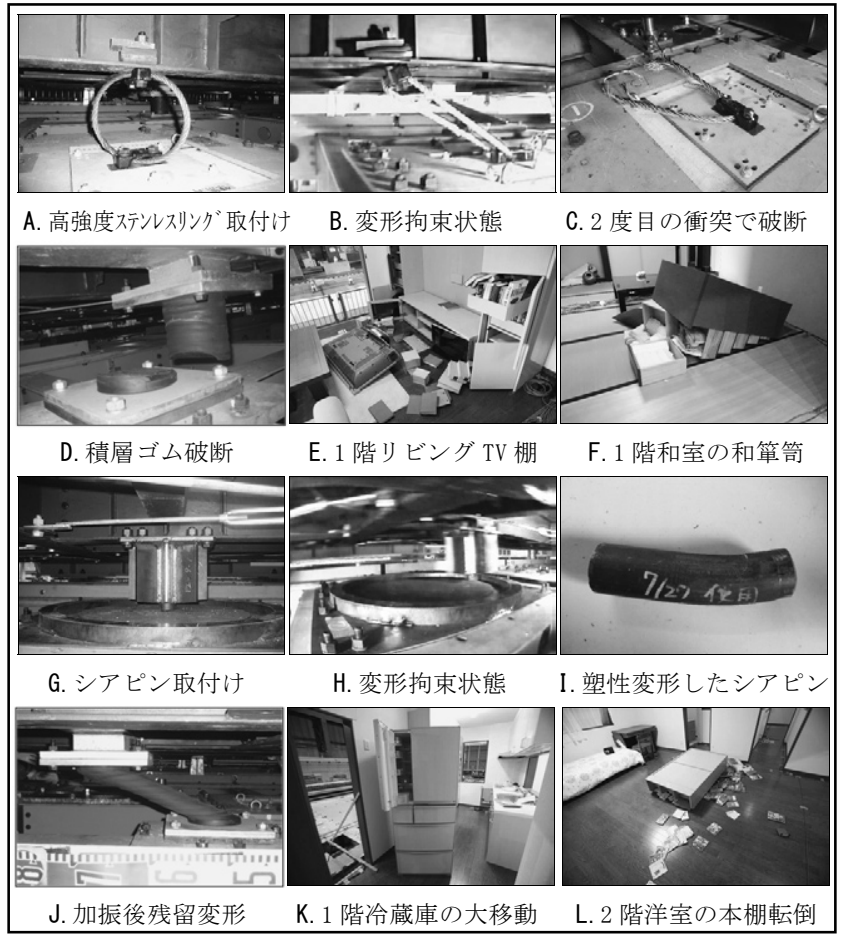

図 27 川口波加振後の記録写真 
高強度ステンレスリングが 2 回目の抑制において、免震層せ 几断力係数 1.0 程度で全基が破 断した現象について考察する。 図 28 は、 4 基の変位計記録を基 に Y1 変位計が- $300 \mathrm{~mm}$ 変形した 時刻における免震層フレームと リングの変形状態を模式的に示 している。1 回目の抑制後、免 震層フレームは右下角部を中心

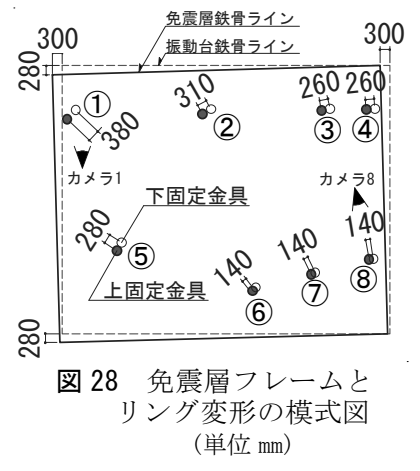

に回転変形しながら水平変形しており、リング 8 基が等しく変形し ていない。変形が最も大きい(1)番リングが最初に作動し、続いて(2) (5) (3)(4)番の一群が連続的に作動し、各々が耐力を上回るせん断力を 負担して順次破断したと推察できる。その後少し時間をおいて(6)(7) (8)番の一群が作動、破断した様子が、図 29 に示すビデオ画像や図 23 のグラフ形状から確認できる。高強度ステンレスリングによる免 震層変形抑制を実現するためには、回転変形を考慮した各リングで の負担せん断力の検討及び設置精度の向上が必須である。
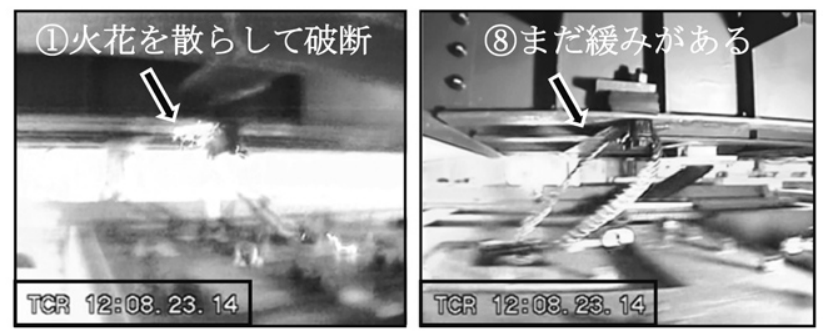

図 29 同時刻(タイムスタンプ 12 時 8 分 23 秒 14)における 高強度ステンレスリングの作動状況 (左(1)番、右(8)番)

\section{5. 実大震動台実験第 4 期：免震層応答速度感応タイプ}

5 章では免震層応答速度に応じて免震層変形を連続的かつ継続的 に抑制する特殊オイルダンパ(以後、ダンパ)について検討する。

図 30 に全体形状と寸法を示す。有効ストロークは土 $55 \mathrm{~cm}$ である。

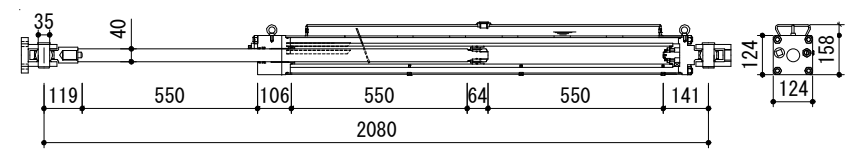

図 30 本ダンパの全体形状及び寸法

\section{1 ダンパの特徵及び減衰力発生機構}

通常の設計レベルの地震動に対しては現行の免震システムで減衰 性能は満足できるので、変形抑制装置の減衰力は極力小さくしたい。 一方、通常の設計レベルを超える地震動に対しては大きな減衰力を 得られるようにしたい。筆者らはこの棲み分けを実現させるために、 2 期に免震層応答速度に応じて減衰力を機械的に 2 段階に切り替え る機構を有するオイルダンパの検討を行った。1 期の免震層変形拘 束タイプと比較すると応答加速度は低減できたが、依然として衝撃 は大きく、建物内部の安全性を確保寸るには至らなかった ${ }^{25)}$ これ は減衰力の切り替えを急激に行うことで、応答速度と減衰力の関係 に不連続が生じることが主な原因であった。このため、4 期では減
衰力が応答速度に応じて連続的に変 化するように工夫した。

従来型のオイルダンパの減衰力は ピストン速度に応じて連続的に変化 する特徵を持つが、免震建物に用い る一般的なオイルダンパは図 31 に 示すように減衰力がピストン速度に 比例するように設計され、リニア型、 バイリニア型と呼ばれている ${ }^{26)}$

小さな摇れの低速度領域では減衰

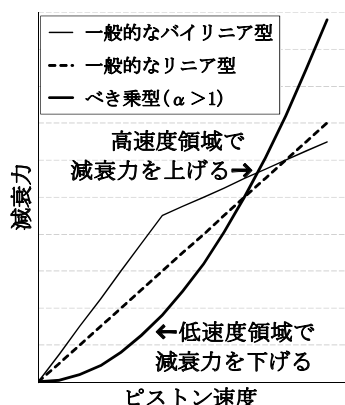

図 31 リニア型とべき乗型 力をなるべく小さくし、極めて強い

摇れとなる高速度領域で大きな減衰力を得るようにするには、ピス トン速度と減衰力の関係はリニア型ではなく、べき乗型 $(\alpha>1)$ であ ることが望ましい。そこで、ダンパヘッド部にオリフィス（絞り孔） を設けることで減衰力がピストン速度の二乗に比例するようにする。 減衰力は作動油がオリフィスを通過する前後で生じる圧力差による 動圧抵抗によって発生する。この時作動油は高圧力となり、オリフ イスを通過して噴出される過程で熱エネルギに変換される。

オリフィス内を通過する作動油の減衰力は次式で表わされる ${ }^{27)}$ $F(v)=8 \pi \mu L A^{2} \cdot \frac{v}{a^{2}}+\frac{\gamma}{2 g} \cdot \frac{A^{3}}{c_{d}^{2} a^{2}} \cdot v^{2}$

ここに、 $F(v)$ : 減衰力、 $\mu$ : 作動油の粘性係数、 $L$ :オリフィス長 $A$ : ピストン面積、 $a$ :オリフィス面積、 $\gamma$ : 作動油の比重 $g$ :重力加速度、 $C_{d}$ : 流量係数、 $v$ : ピストン速度

上式第 1 項はオリフィス内部の層流の粘性抵抗から生じる減衰力、 第 2 項はオリフィス前後で起こる乱流による減衰力である。本ダン パにおいて層流区間は極く短く、第 1 項は事実上無視して問題ない。 減衰力は全てオリフィス前後での減衰力で決まると考えると、

$F(v)=C_{1} v^{\alpha}\left(C_{1}\right.$ : 減衰係数 $)$

のように、べき乗型 $(\alpha=2)$ となる。

一方で、減衰力がピストン速度 (以後、速度)の二乗に比例して増 加すると、高速度領域で減衰力が著しく大きくなる。その対応とし てリリーフ弁によるバイパス通路を作り、高速度領域ではリリーフ 弁が開いて減衰力の急激な上昇を抑える(図 32)。この時の減衰力を リリーフ荷重 $F_{1}$ 、速度をリリーフ速度 $V_{1}$ と呼ぶ。

$V_{1}$ より高速度領域における速度と減衰力の関係は、

$F(v)=F_{1}+C_{2}\left(v-v_{1}\right)\left(C_{2}\right.$ : 減衰係数 $)$

となり、速度と $F_{1}$ からの増分減衰力の関係は線形 $(\alpha=1)$ となる。

$V_{1}$ はオリフィス弁、 $F_{1}$ はリリーフ弁で各々設定可能である。

$C_{2}$ はリリーフ弁の

形状で決まり、制作 後は固定される。本 ダンパでは $V_{1}$ 及び

$F_{1}$ は本体外部から 連続的に調整できる ように設計している。

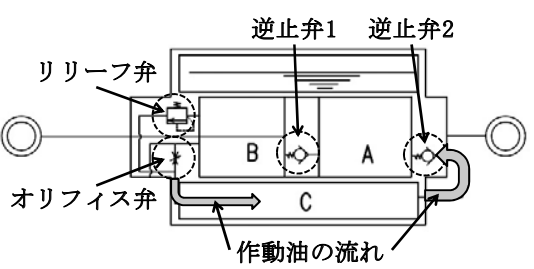

図 32 対象ダンパの回路図

\section{2 減衰力特性}

対象ダンパはユニフロー型で、図 32 に示す逆止弁 1 及び 2 が交互 に開閉することで、ピストンの伸長時も圧縮時も作動油が常に B 室 からオリフィス又はリリーフ弁を通過して C 室に流れる特徵を持つ。 
ダンパの全長を短く設計でき、狭小な住宅の免震層設置に有効であ る。実大震動台実験に先立ち、専用のダンパ試験機による予備試験 を行った。加振波は周期 1.26 秒 (一定)の $\sin$ 波で、1 サイクル毎に 変位振幅が $5 \mathrm{~cm}$ ずつ増大寸る試験波 (以後、漸増 $\sin$ 波) とした。6 サイクル加振で変位振幅は $5 \mathrm{~cm}$ から $30 \mathrm{~cm}$ まで、速度振幅は $25 \mathrm{~cm} / \mathrm{s}$ から $150 \mathrm{~cm} / \mathrm{s}$ まで増大寸る(図 33、図 34)。

図 35 及び図 36 に漸増 $\sin$ 波加振時の減衰力と变形及び速度の関 係を示す。伸長時の減衰力を正、圧縮時を負とする。本研究では、 図 36 における速度振幅 $150 \mathrm{~cm} / \mathrm{s}$ ループにおけるリリーフ速度を $V_{1}$ 、 リリーフ荷重を $F_{1}$ と定義した。そして、予備試験の結果からダンパ の力学的特性を単純化し、パラメトリックスタディに基づいて、最 大応答加速度が最適となる $V_{1} 、 F_{1} 、 C_{2}$ 及び摩擦係数 $\mu$ の組み合わせ を探った。その際に、選定した入力波に対して免震層の最大変形を、 4 章で目標とした $35 \mathrm{~cm}$ から $40 \mathrm{~cm}$ に抑制することを目安とした。そ の結果、 $V_{1}=100 \mathrm{~cm} / \mathrm{s} 、 F_{1}=65 \mathrm{kN} 、 C_{2}=0.2 \mathrm{kN} / \mathrm{cm} / \mathrm{s} 、 \mu=0.03$ が得られ、 これらを震動台実験における標準設定值とした。

\section{3 実験概要}

図 37 に示すように、本ダンパを免震層 X方向と $\mathrm{Y}$ 方向に 2 基ずつ、 伸長時と圧縮時の速度と減衰力特性を補完し合うよう、逆向きに配 置する。表 3 に加振日毎のダンパ 1 基あたりの $F_{1}$ を示す。標準設定 である $F_{1}=65 \mathrm{kN}$ から開始し、加振毎に免震層の最大変形と応答加速

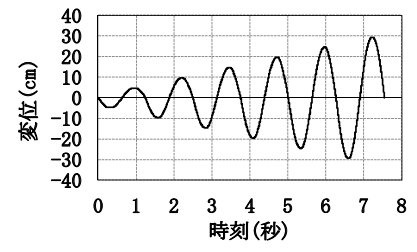

図 33 変位振幅

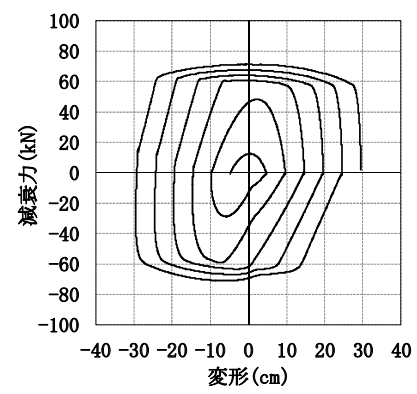

図 35 変形と減衰力

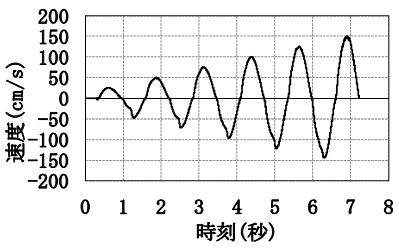

図 34 速度振幅

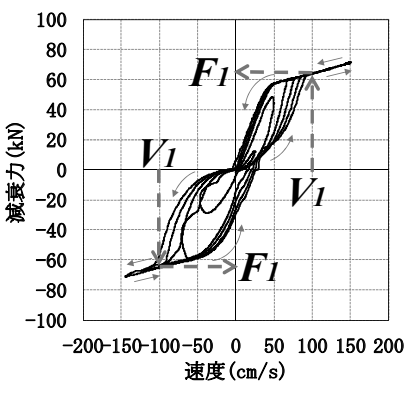

図 36 速度と減衰力

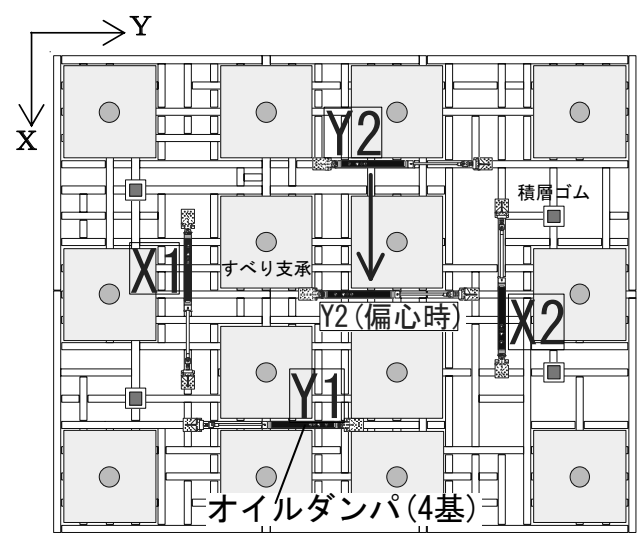

図 37 オイルダンパ配置図
度及び家具類の転倒状況などを確認しながら、 $V_{1}$ は固定として $F_{1}$ のみを段階的に低減し、最終日は初日の $1 / 2$ 以下の $F_{1}$ とした。

また $F_{1}=30 \mathrm{kN}$ 設定では、図中 Y 2 ダンパのみを免震層中央部に移動 し、極端な偏心配置による免震層変形抑制の影響を確認した。最後 に比較のため免震層を固定した非免震状態による加振も実施した。

\section{4 ダンパ比率と最大応答加速度}

実験対象住宅の総重量 $W$ に対する本ダンパ 1 方向 2 基の $F_{1}$ の比 $\left(2 F_{1} / W\right)$ をダンパ比率 $\beta$ とする。図 38 、図 39 に $\beta$ と 1 階床及び 2 階床の最大応答加速度の関係を入力波毎に示す。全ての入力波は震 動台 XY45 度方向を主軸として加振 (以後、XY 主軸加振) している。 $\beta=26.5 \%$ (標準設定)において全ての入力波に対して免震層の最大 変形が $35 \mathrm{~cm}$ 程度に抑制され、最大応答加速度は鷹取波で $550 \mathrm{~cm} / \mathrm{s}^{2}$ 、 川口波や莫合波、柏崎波で $450 \mathrm{~cm} / \mathrm{s}^{2}$ 以下となった。これらは全て最 大入力加速度を下回っている。しかし、建物内部では什器類の飛散 が見られた。 $\beta$ の低減と対応するように、建物内部の摇れは徐々に 穏やかになり、 $\beta=16.3 \%$ 以の加振では全ての入力波に対して家具類、 什器類の転倒飛散が皆無となった。足柄波では終始穏やかであった。 $\beta=12.2 \%$ の加振では 1 階床での最大応答加速度は鷹取波、川口波、 柏崎波、亘合波、上町断層波で $300 \sim 400 \mathrm{~cm} / \mathrm{s}^{2}$ 、神戸波で $250 \mathrm{~cm} / \mathrm{s}^{2}$ 、 足柄波、古川波、告示波で $200 \mathrm{~cm} / \mathrm{s}^{2}$ 前後に抑制され、免震住宅とし て建物内部の安全性を確保することができた(図 40)。また、Y2 ダン パの偏心設置による最大応答加速度への影響は見られなかった。

表 3 加振日及び $F_{1}$

\begin{tabular}{|c|c|c|c|}
\hline 加振日 & $F_{1}$ & 加振日 & $F_{1}$ \\
\hline 7 月 5 日 & $65 \mathrm{kN}$ & 7 月 18 日 & $50 \mathrm{kN}, 45 \mathrm{kN}$ \\
\hline 7 月 6 日 & $60 \mathrm{kN}$ & 7 月 19 日 & $40 \mathrm{kN}, 30 \mathrm{kN}$ (偏心配置) \\
\hline 7 月 17 日 & $60 \mathrm{kN}, 55 \mathrm{kN}$ & 7 月 20 日 & $30 \mathrm{kN}$ (偏心配置), 非免震 \\
\hline
\end{tabular}
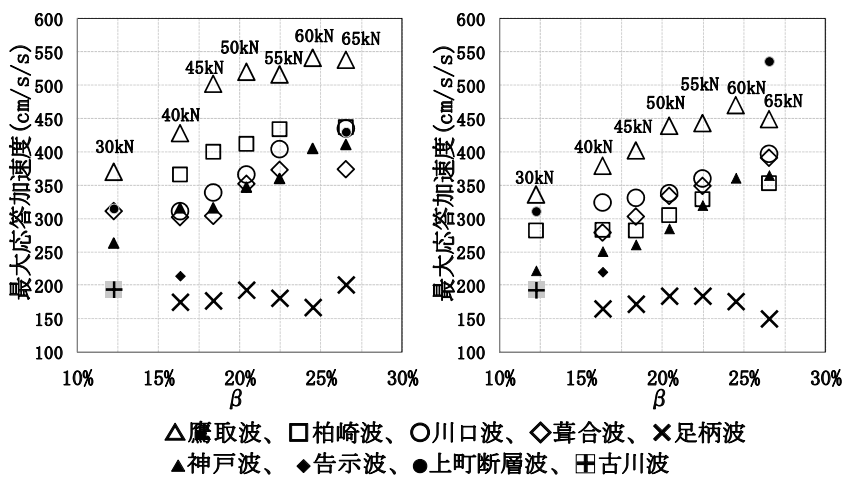

$\Delta$ 鷹取波、口柏崎波、O川口 、神戸波、・告示波、・上町断層波、田古川波

図 381 階床最大応答加速度 図 392 階床最大応答加速度

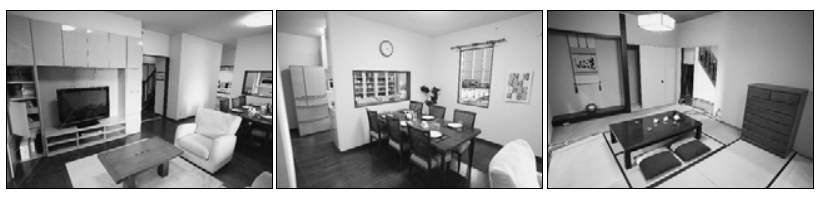

図 40 鷹取波加振後の建物内部の様子 $(\beta=12.2 \%)$

\section{5 免震層変形軌跡}

4 期では図 41 に示すリアルタイム画像 処理によるカメラ変位計 2 基を、図 4 の 免震層装置配置図 (4 期) に示寸位置に導 入し、水平 2 方向の高速変形に対する計 測精度の向上を試みた ${ }^{28)}$

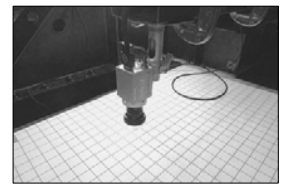

図 41 カメラ変位計 
図 42 から図 50 に全ての入力波で XY 主軸加振した時の免震層変形 軌跡を示寸。免震層変形は変位計 2 基の平均值とし、各入力波の代 表的な $\beta$ による免震層変形軌跡を重初描いている。図中の点線四角 は現行の寸べり支承サイズ $(80 \mathrm{~cm}$ 角) を示し、実線四角は $1 \mathrm{~m}$ 角の滑 り支承に相当する。 $\beta$ の低減と共に免震層変形が増大寸る傾向が見 られる。XY 主軸加振では全ての地震動 (告示波は一方向加振) で現行 の可動範囲内に納まる免震層変形に抑制することが可能となった。

図 51 及び図 52 に入力主軸方向の違いによる免震層変形軌跡比較 の一例として柏崎波、鷹取波の実験結果を示す。XY 主軸加振に対し $\mathrm{Y}$ 主軸加振では大変形時における軌跡の膨らみが減少し、免震層の 最大変形は柏崎波で 1 割、鷹取波で約 2 割増大寸る傾向が見られた。 このように、入力主軸方向や実際の摺動子面の大きさを考慮した変 形に対して余裕度を確保するためには、1m 角のすべり支承サイズが 理想的である。住宅地において、10cm のクリアランス拡張は決して 簡単ではないが、現実的には対応可能な大きさであると考えている。

※下図縦軸横軸は変形 $(\mathrm{cm})$ で 1 目盛は $10 \mathrm{~cm} \% \%$ $\beta$ の值とする。

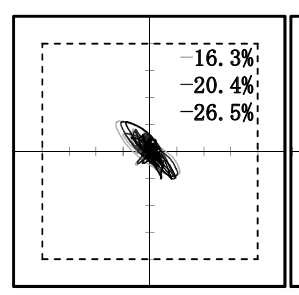

図 42 足柄波

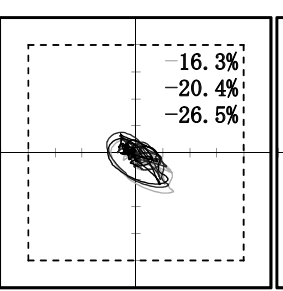

図 45 神戸波

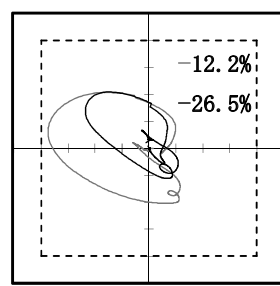

図 48 上町断層波

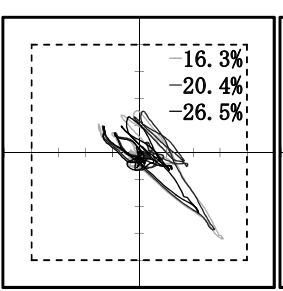

図 43 川口波

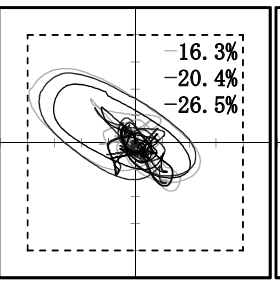

図 46 鷹取波

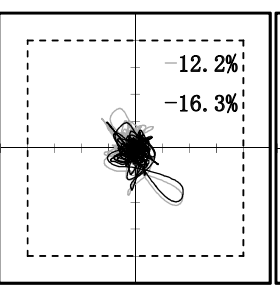

図 49 古川波

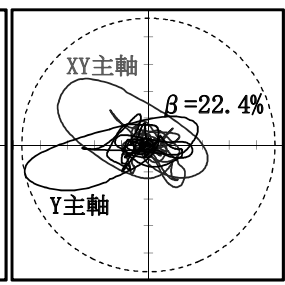

図 52 鷹取波

\section{6 川口波加振：変形抑制装置の性能比較}

3 章及び 4 章と本章の結果を比較するために、 $\beta=12.2 \%$ とした川口 波 Y 主軸加振について検討する。

図 53 に免震層変形とせん断力係数を示す。免震層の最大せん断力
係数は 0.3 程度となり、変形抑制装置を設置しない加振結果と同程 度の応答に保ちながら、免震層の最大変形を約 $60 \%$ に抑制している。 この時、Y 方向に設置した 2 基のダンパは、図 54 に示す速度と減衰 力の関係において 2 基とも概水目標通りの $F_{1} 、 V_{1} 、 C_{2}$ を再現してお り、実地震動に対しても減衰力は正しく発揮されている。

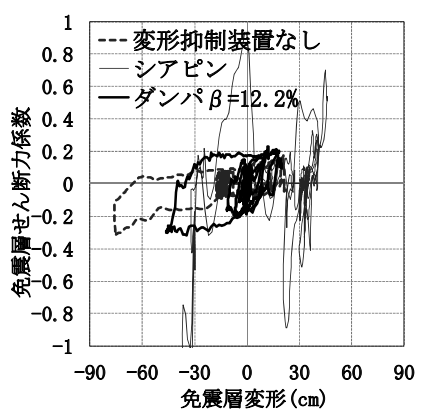

図 53 免震層変形とせん断力係数

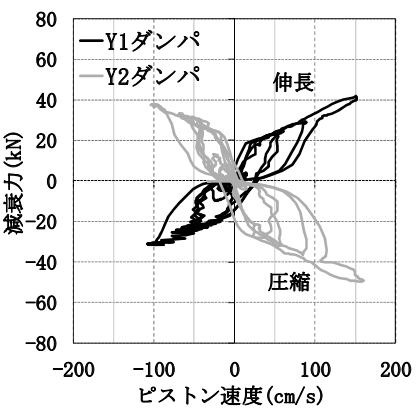

図 54 速度と減衰力
図 55 に川口波 Y 主軸加振時の各階最大応答加速度分布を示す。 居住空間である 1 階及び 2 階において、高強度ステンレスリング 及びシアピンの免震層変形拘束タイプでは非免震の 2 倍から 4 倍の 大きな応答加速度が生じている。一方、免震層応答速度感応タイプ のダンパでは、非免震の $1 / 3$ から $1 / 4$ に低減しており、変形抑制装 置を設置しない状態に近い最大応答加速度分布となっている。

図 56 に 1 階床中央の時刻歴加速度記録から算出した加速度応答ス ペクトル $(h=0.05)$ を示す。全ての加振で 1.3 秒付近に明瞭なピーク 見られる。非免震とシアピンで大きく、川口波の強烈なパルス周期 の影響と推察される。周期 0.1 秒から 1.0 秒において、免震層変形 拘束タイプの応答加速度は非免震を上回るがダンパでは下回り、周 期 0.1 秒から 0.5 秒付近までは変形抑制装置なしの応答スペクトル に近接している。 0.1 秒から 1.0 秒の振動周期帯は人体感覚と対応 すると言われるが 29)、ダンパは当該周期帯の応答加速度を免震層変 形拘束タイプの $2 / 3$ から $1 / 10$ に低減しており、変形抑制時の衝撃的 な摇れに対する居住者の恐怖感軽減に寄与するものと考えられる。

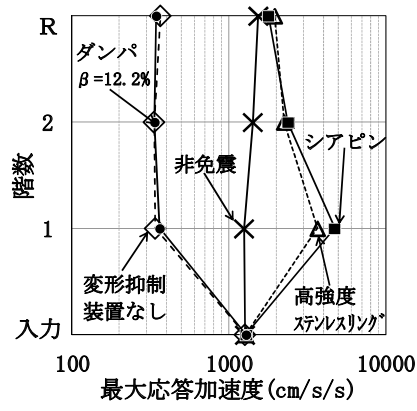

図 55 最大応答加速度分布

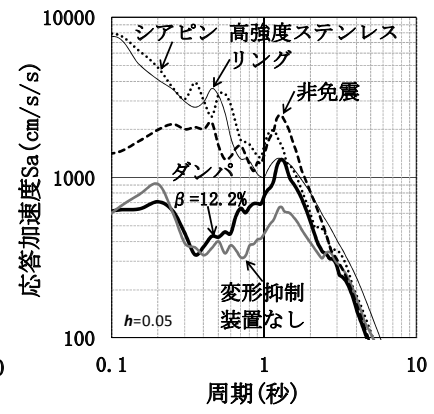

図 56 加速度応答スペクトル

\section{6. まとめ}

実大震動台実験に基づく実証的な見地から以下の結論を得た。 免震層変形拘束タイプの変形抑制装置は、免震層の応答速度が比 較的小さい長周期地震動に対して有効であるが、応答速度が極めて 大きくなる断層近傍の巨大地震動に対する衝撃力は甚大で、建物内 部は非常に危険な状態となった。一方、免震層応答速度に応じて減 衰力がべき乗で変化する特殊オイルダンパでは、適切なダンパ比率 
$\beta$ を採用することで、本研究で対象とした全ての地震動に対して、 免震層変形を現実的な大きさに抑制し、同時に建物内部の安全性を 確保することが可能となった。

既往の研究結果として、大大特 ${ }^{22}$ では、対象免震住宅に減衰こま RDT（Rotary Damping Tube）を採用して変形抑制を試みているが、川 口波 $95 \%$ 入力に対して免震層変形は $50 \mathrm{~cm}$ を超え、十分な効果は得ら れなかったと結論している。また、すべり支承を有する 2 階建て木 造免震住宅に対する連結機構摩擦ダンパFDC (Friction Damper with

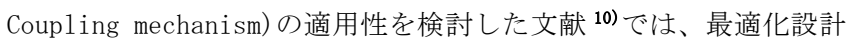
手法による鷹取波の解析において、免震層最大変形を $30 \mathrm{~cm}$ 以内に抑 制する場合、上部構造の最大応答加速度は $1000 \mathrm{~cm} / \mathrm{s}^{2}$ を超える結果 となっている。更に、戸建免震住宅に速度比例 (リニア)型のオイル ダンパを用いた実大震動台実験の報告 ${ }^{30,31)}$ では、本研究で対象とし た大規模な地震動に対する応答までは検証されていない。

以上のような状況からも本研究成果の優位性が示される。しかし、 完全に同じ条件での比較は実証的な見地からは難しく、数值解析に 頼らざるを得ないため、論を改めて検討したい。また、本研究にお ける実験条件は限られており、建物内部の家具類についても実生活 においては様々である。このことを銘記し、今後はダンパ力学的特 性の高度なモデル化と、将来発生が懸念される巨大地震動を含め、 多種多様な地震動に対する応答シミュレーションを課題とし、免震 層変形抑制に対する免震住宅の更なるロバスト性向上に繋げたい。

\section{謝辞}

本研究では神戸海洋気象台、JR 鷹取駅、大阪ガス蕞合供給所、 SK-net、K-NET における貴重な地震観測記録と、JSCA 関西による模 擬地震動を使用させて頂きました。

(有)シズメテックの鎮目武治氏には、本ダンパの共同開発と供試体 の制作において多大なるお力を頂きました。

信州大学工学部建築学科の田守伸一郎准教授、㑣)日本システム設 計の三宅辰哉氏、松本和行氏には実大震動台実験において終始㱢篤 なるご指導を賜りました。また、カメラ変位計測には東京電機大学 情報環境学部の新津靖教授、東京都市大学工学部の古屋治准教授に ご協力を頂きました。心より感謝申し上げます。

\section{参考文献}

1）一般社団法人日本建築学会：長周期地震動と超高層建物の対応策，一専 門家として知っておきたいこと一, 2013.10

2) 一般社団法人日本免震構造協会, 応答制御建築物調查委員会 : 東北地方 太平洋沖地震に対する応答制御建築物調査報告会, 2012.1

3）古澤健, 酒井和成, 清水輝文, 諸藤弘之: 東北地方太平洋沖地震におけ る免震構造の観測記録と居住者へのアンケート調査及び応急点検, 一般 社団法人日本免震構造協会 MENSHIN 第 73 号 pp. 23-28, 2011.8

4）高橋武宏, 福和伸夫 : 2011 年東北地方太平洋沖地震における戸建免震住 宅の免震層変形と足柄平野の地盤震動特性との関係, 日本建築学会構造 系論文集第 694 号，pp. 2123-2132，2013. 12

5）島村淳, 松本優資, 奥中良佑, 柏尚稔, 宮本裕司：複合改良地盤を用い た擁壁と免震建物の衝突応答低減に関する基礎的研究, 日本建築学会構 造系論文集第 684 号, pp309-316,2013.2

6）南海トラフの巨大地震モデル検討会 : 第二次報告 強震断層モデル編-強 震断層モデルと震度分布について-, 2012.8

7）古村孝志，前田拓人：東北地方太平洋沖地震を踏まえた、南海トラフ地 震の時間差連動による長周期地震動の再評価, 日本地球惑星科学連合 2012.5.21

8）三輪田吾郎，小巻潤平，佐藤浩太郎，佐野剛志，勝俣英雄，多幾山法子, 林康裕：実大免震建物の擁壁衝突実験とそのシミュレーション解析，日 本建築学会構造系論文集第 663 号, pp. 899-908, 2011.5
9）独立行政法人防災科学技術研究所 兵庫耐震工学研究センター：実大免 震建物の衝突による被害低減対策開発のための加振実験 (公開実験), 2013.8

10）池永昌容, 福見祐司, 五十子幸樹, 井上範夫 : 地震入力レベルを考慮し た連結機構摩擦ダンパーの免震戸建住宅への適用性, 日本建築学会構造 系論文集第 690 号, pp. 1413-1422, 2013.8

11）安田拓矢, 森高英夫, 築谷朋也, 福和伸夫 : 免震ダンパー接続型付加減 衰機構の開発, その 1 開発意図とモデルスケールスタディー, 日本建 築学会大会学術講演梗概集，構造 II , pp. 275-276, 2012.9

12）株式会社一条工務店ホームページ, http://www. ichijo. co.jp/technology/menshin/, 2013.12.12 参照

13）平野茂, 飯場正紀, 高橋武宏, 松本和行, 三宅辰哉, 坂本功 : 2011 年東 北地方太平洋沖地震における戸建免震住宅の地震時挙動，その 1 東日本 地域における免震住宅の地震時挙動, 日本建築学会大会学術講演梗概集, 構造 II ，pp. 511-512，2012.9

14）飯場正紀, 小豆畑達哉, 井上波彦, 平野茂 : 2011 年東北地方太平洋沖地 震における戸建免震住宅の地震時挙動, その 2 宮城県内の戸建免震住宅 の調査および変位応答と近傍地震動の関係, 日本建築学会大会学術講演 梗概集，構造 II ，pp. 513-514，2012.9

15）総務省統計局ホームページ, http://www. stat. go. jp/data/, 2013.9.4 参照

16）国土交通省北陸地方整備局ホームページ, 新潟県中越地震, http://www. hrr.mlit. go. jp/saigai/H161023/chuetsu-jishin/, 2013.9.4 参照

17）一般社団法人日本免震構造協会ホームページ, http://www. jssi. or. jp/, 2013.12.12 参照

18）源栄正人，永野正行：深部不整形地下構造を考慮した神戸市の地震動の 増幅特性解析, 一兵庫県南部地震における「震災の帯」の解釈一, 日本 建築学会構造系論文集第 488 号, pp39-48, 1996.10

19）坂本功：兵庫県南部地震以後の振動台実験概観, JAEE 日本地震工学会誌 No. $2,2005.8$

20）林康裕：パルス性地震動の特徵と耐震設計の方向性，活断層を考慮した 設計用地震荷重, 日本建築学会大会構造部門(振動) パネルディスカッ ション資料, 日本建築学会 構造委員会 振動運営委員会, 2011.8

21）平野茂, 三宅辰哉, 深堀美英, 花井勉, 坂本功 : 実大震動実験に基づく 木造免震住宅の地震応答評価手法に関する研究，その 1 実験結果なら びに 1 質点振動モデルを用いた解析的考察, 日本建築学会構造系論文集 第 529 号，pp. 65-72，2000.3

22）平野茂, 三宅辰哉, 花井勉, 五十田博, 箕輪親宏, 藤田聡 : 震動台によ る既存木造住宅の耐震性能検証実験，その 7 木造免震住宅の想定外入力 実験, 日本建築学会大会学術講演梗概集 B-2 分冊, pp. 659-660, 2006.9

23）高橋武宏，穴原一範，深堀美英：水平変位制御によって免震建物に発生 する衝撃力に関する実大実験と応答解析, 日本建築学会構造系論文集第 573 号，pp. 223-230，2003. 11

24）伊村則子，石川考重：地震時の家具類転倒・落下防止対策の現状と効果 の検証, 日本建築学会住宅系研究論文報告会論文集 1, pp. 47-53, 2006. 12

25）河尻出，松本和行，三宅辰哉，平野茂，高橋武宏，福和伸夫：振動台実 験に基づく速度感応型性能可変ダンパを用いた小規模免震住宅の変位制 御に関する研究，その 4 実大振動台実験[Phase2]における応答性状及び 家具等の転倒状況, 日本建築学会大会学術講演梗概集, 構造 II, pp. 483-484, 2013. 8

26）露木保男，小倉雅則，河相崇，中野智和，高橋治，岡部富雄，曽田五月 也, 中込忠男：住宅用高減衰免震システムの開発，その 3 オイルダンパ 一の設計と要素実験, 日本建築学会大会学術講演梗概集 B-2 分冊, pp. 531-532, 2003. 9

27）砂子田勝昭，袖山博：オイルダンパの設計手法に関する研究，減衰力発 生の基礎的検討, 日本機械学会機械力学・計測制御講演論文集 No. 98-8, pp. 84-87, 1998.8

28）新津靖, 飯塚崇明, 安岡賢太, 古谷治：リアルタイム画像処理による格 子ラインの二次元変位計測, 日本実験力学会 2012 年度年次講演会, No. 12-123, pp. 1-4, 2012.7

29）境有紀，神野達夫，纐纈一起：建物被害と人体感覚を考慮した震度算定 方法の提案, 第 11 回日本地震工学シンポジウム論文集, 2002.11

30）横林優，横山重和，紀本亨，東田豊彦，箭野憲一，片村立太 : 戸建て免 震住宅の実大振動実験, その 1 実験概要と建物の振動特性, 日本建築学 会大会学術講演梗概集 B-2 分冊, pp. 417-418, 2004. 8

31）横山重和, 横林優, 東田豊彦, 西崎誠, 箭野憲一, 片村立太 : 戸建て免 震住宅の実大振動実験，その 2 実験結果および考察，日本建築学会大会 学術講演梗概集 B-2 分冊, pp. 419-420, 2004.8 